\title{
Free Ammonia Deliming: Effect of Tartaric Acid Addition as a Deliming Agent on The Quality of Wet Blue and Wastewater
}

\author{
A. W. Nugraha ${ }^{\mathrm{a}, *}$, O. Suparno ${ }^{\mathrm{a}}$, N. S. Indrasti ${ }^{\mathrm{a}}$, \& Hoerudin $^{\mathrm{b}}$ \\ ${ }^{a}$ Department of Agro-Industrial Engineering, Faculty of Agricultural Technology, IPB University \\ (Bogor Agricultural University) \\ Kampus IPB Dramaga, Bogor, Jawa Barat 16680, Indonesia \\ ${ }^{b}$ Indonesian Center for Agricultural Post Harvest Research and Development \\ Jalan Tentara Pelajar No 12, Cibogor, Kecamatan Bogor Tengah, Kota Bogor, Jawa Barat 16122, Indonesia \\ *Corresponding author: aditya.wahyu28@gmail.com \\ (Received 25-09-2019; Revised 27-01-2020; Accepted 12-02-2020)
}

\begin{abstract}
The objective of this study was to evaluate the pelt and wastewater characteristics after deliming process in an acid condition by tartaric acid, also wet blue properties that were formed. Various observed variables were the dose of tartaric acid, pelt thickness, calcium content, physical and chemical properties of wet blue, such as tensile strength, tear strength, elongation, shrinkage temperature, and chrome oxide content, as well as the pollutants content of wastewater as chemical oxygen demand (COD), biological oxygen demand (BOD), total suspended solid (TSS), and total dissolve solid (TDS). The experiment used a completely randomized design with a factorial arrangement. The first factor was $\mathrm{pH}$ variables consisted of 3 levels, i.e., 4, 5, and 6 in the final deliming solution. The second factor was the deliming time consisted of 3 levels, i.e., $45 \mathrm{~min}$, $60 \mathrm{~min}$, and $75 \mathrm{~min}$. Data were analyzed using Analysis of Variance (ANOVA) and then Duncan's Multiple Range Test (DMRT). The results showed that deliming for $60 \mathrm{~min}$ and the $\mathrm{pH}$ of 5 at the end of the solution was the best treatment to remove calcium content in the pelt and reduce the thickness of pelt. It did not affect the physical and chemical quality, such as tensile strength, tear strength, elongation at break, and shrinkage temperature of the wet blue produced. Also, the quality of wastewater produced was better than the use of ammonium sulfate as a deliming agent. It can be concluded that the use of tartaric acid as $\mathrm{pH}$ regulator of deliming stage at $\mathrm{pH} 5$ for $60 \mathrm{~min}$ can be used as an alternative deliming agent to substitute ammonium sulfate.
\end{abstract}

Keywords: tartaric acid; deliming agent; wet blue; wastewater

\section{INTRODUCTION}

Skin or hide is the by-product of animal slaughtering that can be used as a raw material for the wet blue product. There are several steps used to convert animal skin or hide to be a wet blue, including liming and deliming. Liming is one of the tanning stages that aimed to eliminate non-collagen components from the skin, open skin fiber tissue, swell the skin, hydrolysis the peptide bond and fats, etc. (Covington \& Wise, 2019; Colak \& Kilic, 2007). Another effect of the liming step is the formation of carboxyl active groups and active amino groups (Colak \& Kilic, 2007).

Deliming is another step of tanning that is carried out after the liming process. The purpose of this process is to remove the lime from the skin, reduce the $\mathrm{pH}$, and deswelling the skin (Covington \& Wise 2019). Deliming is done by lowering the $\mathrm{pH}$, deswelling, and preparing the skin for the bating process (Sivakumar et al., 2015). In the conventional process, the deliming process requires the addition of ammonium sulfate. The ammonium sulfate can quickly penetrate the skin (Uddin et al., 2018; Chowdhury et al., 2018). As the consequences of ammonium sulfate application in a tannery, there is ammonia to be discharged into the air and the wastewater, creating environmental problems as ammonia is a toxic substance. In the form of gas, ammonia could endanger workers because it can cause several diseases, i.e., heart attacks, cerebrovascular disease, chronic obstructive pulmonary disease (COPD), asthma, and lung cancer when ammonia bind with the other gases in the atmosphere such as sulfur dioxide and nitrogen dioxide (Guthrie et al., 2018). Besides, ammonia in wastewater could stimulate eutrophication or algae blooming (Dai et al., 2012).

The high content of ammonia in wastewater is one of the problems faced by the tannery. To meet the environmental standard, the industry should minimize or even remove the ammonia content of wastewater, which means the improvement of the production cost for waste handling (Zeng et al., 2011; Uddin et al., 2018). Several methods of end of pipe treatment like absorption (Yunnen et al., 2016; Murti et al., 2013), nanofiltration (Stoller et al., 2013; Gallego-molina et al., 2012), biological treatment (Wang \& Liu 2011; Keerthi et al., 2013), electrochemical treatment (Ghimire et 
al., 2019), and the others have been applied to reduce the pollutants contained in the wastewater. One of them is ammonia. However, the results of some methods are still higher than the environmental standard. There is another method that is possible to be applied, i.e., the substitution of ammonium sulfate. Some chemicals are able to be used as substitutions of ammonium sulfate, i.e., sodium hexametaphosphate, boric acid (Zeng et al., 2011; Wang et al., 2013), glycine (Lei et al., 2019), glycolic acid, EDTA (Uddin et al., 2018), acetic acid, boric acid, citric acid (Colak \& Kilic 2007; Sui et al., 2012), dry ice (Sathish et al., 2013), sulfonated phthalic magnesium salt (Qiang et al., 2012), sodium gluconate (Zeng et al., 2018), and paracetic acid (Sirvaityte et al., 2007).

In general, the deliming process is carried out under a neutral $\mathrm{pH}$ up to a slightly alkaline $\mathrm{pH}$ condition. However, several previous works also reported the deliming process under neutral $\mathrm{pH}$ up to a slightly acidic condition (Covington \& Wise 2019) such as the effect of organic acids addition in the form of paracetic acid (Sirvaityte et al., 2007). A strong odor such as acetic acid or ammonium sulfate could interfere with the workers who are not equipped with the safety equipment. Therefore, it is necessary to use the other organic acids that have no interfering odor, i.e. tartaric acid. Tartaric acid is an odorless organic acid and forms a crystalline solid. Tartaric acid can be used as an acidulant, $\mathrm{pH}$ control agent, preservative, emulsifier, stabilizer, chelating agent, and others (USDA, 2011). The ability of tartaric acid as a chelating agent is expected to bind calcium ion so that calcium can be removed from the pelt. The use of tartaric acid as a deliming agent has not been applied at the deliming stage. Therefore, the purpose of this study was to evaluate the pelt and wastewater characteristic after deliming process in an acid condition by tartaric acid, and also wet blue properties that were formed.

\section{MATERIALS AND METHODS}

This study was carried out by using a wooden drum in a size of $40 \times 30 \mathrm{~cm}$. The sample was prepared from the fresh goatskin. This study used a conventional procedure starting from the presoaking stage up to the tanning stage, except the deliming stage. After the liming process, the pelt was cut into a size of $30 \times 15 \mathrm{~cm}$ at the back of the pelt. There was the addition of chemical substances, namely tartaric acid in the deliming stage. The final $\mathrm{pH}$ in the deliming stage was maintained in the range of $\mathrm{pH} 4 \pm 0.3,5 \pm 0.3$, and $6 \pm 0.3$ (Factor 1 ).

Meanwhile, the deliming time was varied at 45, 60, and 75 minutes (Factor 2). The determination of the final $\mathrm{pH}$ was done by a trial-error experiment according to the time variations. The dose obtained will be used in the main research. The ingredients used in each stage of presoaking to liming were prepared based on the weight of fresh skin. Meanwhile, the deliming to tanning stages were based on the weight of pelt after fleshing (Table 1 ). The procedures of presoaking to liming followed the conventional process. This study design used a completely randomized design with two factors, which were $\mathrm{pH}$ and deliming time. Each factor has three levels and repeating three times. Data were analyzed using ANOVA and any significant differences between treatments were further tested by Duncan Multiple Range test at $\alpha 5 \%$ with SPSS 17.

\section{The Dose of Tartaric Acid}

There was a trial-error process to optimize the final $\mathrm{pH}$ for deliming. The final $\mathrm{pH}$ was determined by adding a certain number of doses into the deliming process based on the specified $\mathrm{pH}$ and time. The $\mathrm{pH}$ measurement was carried out using an electric $\mathrm{pH}$ meter (ASTM, 2001).

Table 1. Process, material, and doses of experimental procedure

\begin{tabular}{|c|c|c|c|}
\hline Processes & Materials & Doses & Remarks \\
\hline \multirow[t]{2}{*}{ Soaking } & Water & $200 \%$ & Drum on 1 h. Drain. \\
\hline & Degreasing agent (DA) & $0.1 \%$ & \\
\hline \multirow[t]{4}{*}{ Liming } & $\mathrm{Na}_{2} \mathrm{~S}$ & $2.5 \%$ & \multirow{4}{*}{$\begin{array}{l}\text { Drum on } 2 \text { h, then on for } 15^{\prime} \text {, off for } 45^{\prime} \text {, repeatedly until } 6 \text { h. Overnight and } \\
\text { then drain. Pelt wash with } 150 \% \text { water }\end{array}$} \\
\hline & $\mathrm{Ca}(\mathrm{OH})_{2}$ & $10 \%$ & \\
\hline & DA & $0.1 \%$ & \\
\hline & Water & $300 \%$ & \\
\hline \multirow[t]{3}{*}{ Deliming } & Ammonium sulfate ${ }^{a}$ & $2.5 \%$ & a was a conventional process, deliming time $60^{\prime}$ \\
\hline & Tartaric acid ${ }^{b}$ & $10 \%$ & $\begin{array}{l}\text { b was research experimental. The experiment includes final } \mathrm{pH} 4,5 \text {, and } 6 \text {, } \\
\text { also deliming time } 45^{\prime}, 60^{\prime} \text {, and } 75^{\prime} \text {. }\end{array}$ \\
\hline & Water & $0.1 \%$ & \\
\hline \multirow[t]{3}{*}{ Bating } & Alkaline bate ${ }^{a}$ & $300 \%$ & a was an enzyme that used in the conventional process. \\
\hline & Acid bate & & b enzyme that was used in the experiment. \\
\hline & & & Bating was done $45^{\prime}$. Then drain and wash the pelt. \\
\hline \multirow[t]{4}{*}{ Pickling } & Water & $100 \%$ & \multirow{4}{*}{$\begin{array}{l}\text { Water and } \mathrm{NaCl} \text { were added together. Drum on } 20^{\prime} \text {. Then, the other materi- } \\
\text { als were added periodically with an interval of } 15^{\prime} \text {. The } \mathrm{pH} \text { of pelt was } 3 .\end{array}$} \\
\hline & $\mathrm{NaCl}$ & $10 \%$ & \\
\hline & Formic acid & $0.6 \%$ & \\
\hline & Sulfuric acid & $0.4 \%$ & \\
\hline \multirow[t]{2}{*}{ Tanning } & Chromium sulphate & $8 \%$ & Chromium Sulphate was added, Drum on $1 \mathrm{~h}$. \\
\hline & Sodium bicarbonate & $1.2 \%$ & $\begin{array}{l}\text { Sodium bicarbonate was added, drum on } 6 \mathrm{~h} \text {. Drain and wash the wet blue. } \\
\text { Aging and toggling. }\end{array}$ \\
\hline
\end{tabular}




\section{The Measurement of Pelt Thickness Reduction (SLP 4)}

The thickness of the pelt was measured both after the fleshing stage and after the deliming stage. The measurements were conducted on three points of the pelt by using a thickness gauge for 15 seconds or until constant (SLTC, 1996).

\section{The Decrease of Calcium Content in the Pelt}

The calcium content was measured by using the atomic absorption spectrophotometric (AAS) method (APHA, 2017). The sample was prepared from the pelt after the fleshing and deliming process.

\section{The Test of Physical and Chemical Properties of the Wet Blue}

The observed variables of physical properties were tear strength (SLP 7), tensile strength (SLP 6), elongation (SLP 6), shrinkage temperature (SLP 18), and chromium oxide content (SLC 7). The sample was conditioned at 23 $\pm 2{ }^{\circ} \mathrm{C}$ and $50 \pm 5 \%$ relative humidity $(\mathrm{RH})$ before the test. The conditioning process was carried out for 48 hours (SLTC, 1996).

\section{The Characteristics of Wastewater Pollutants}

The formed wastewater was prepared for some analysis such as ammonia, Chemical Oxygen Demand (COD), Biological Oxygen Demand (BOD), Total Suspended Solid (TSS), and Total Dissolve Solid (TDS) (APHA, 2017).

\section{RESULTS}

\section{The Dose of Tartaric Acid}

Figure 1 showed the experimental result of $\mathrm{pH}$ optimization. Based on Table 2, the deliming time and $\mathrm{pH}$ affected the dose of tartaric acid used in the determining process. The $\mathrm{pH}$ and deliming time had significant effects on the increase in the dose of tartaric acid to reach the final $\mathrm{pH} 4,5$, and $6(\mathrm{p}<0.05)$. Meanwhile, the result of variance analysis showed that the interactions between both factors did not affect the dose of tartaric acid. There was a decrease in tartaric acid dose to reach the final $\mathrm{pH}$ 4, 5, and 6 in different deliming times (Figure 1). The

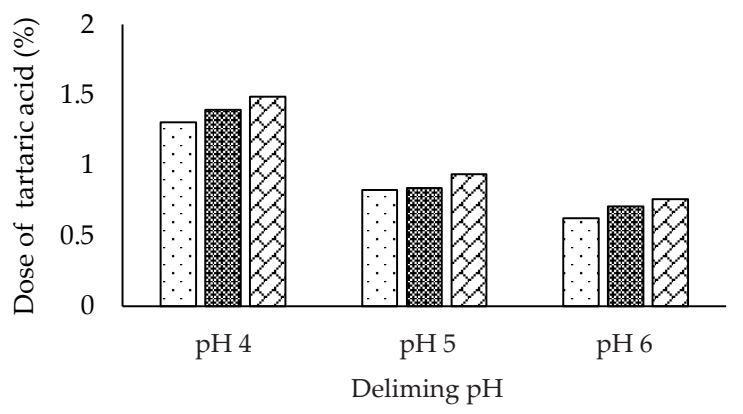

Figure 1. Dose of tartaric acid at different deliming $\mathrm{pHs}$ and times, $\square 45 \mathrm{~min} 60 \mathrm{~min}$ 口 $75 \mathrm{~min}$ addition of tartaric acid dose also affected the initial $\mathrm{pH}$ and final $\mathrm{pH}$ of deliming solution (Table 3). Then, Figure 1 showed that the determination of the final $\mathrm{pH} 4$ required a higher dose of tartaric acid than for determinations of final pH 5 and 6. Similar things occurred, i.e., the determination of final $\mathrm{pH} 5$ required more acid than for determination of final $\mathrm{pH}$ 6. The addition of tartaric acid dose was directly proportional to the length of deliming time, although it was not significantly different.

\section{The Decrease of Pelt Thickness}

Table 4 showed that each factor significantly affected the reduction in pelt thickness $(p<0.05)$. However, the interaction between the two factors did not show a significant effect $(p>0.05)$. Meanwhile, the results of ANOVA on the treatment with conventional treatment showed a significant effect $(p<0.05)$ (Table 4$)$.

Table 5 showed that the treatment of 75 minutes of deliming time with a final $\mathrm{pH}$ of 5 gave the highest reduction in pelt thickness into $45.58 \pm 1.98 \%$, but it was not significantly different compared to the 60 minutes deliming time with the final $\mathrm{pH}$ of 5 , i.e., $43.55 \pm 2.32 \%$. This value also shows that in the treatment, it has a higher value compared to conventional treatments, i.e., $43.20 \pm 1.43 \%$. The pelt thicknesses of the other treatments ware below those resulted from conventional treatments. The treatment of 45 minutes deliming time and final $\mathrm{pH}$ of 4 showed the lowest reduction rates, i.e., $35.81 \pm 0.87 \%$ (Table 5). Thus, the $\mathrm{pH}$ of 5 is the best parameter compared to the other $\mathrm{pH}$ values. The deliming time of both 60 and 75 minutes did not significantly affect the pelt thickness.

Table 2. Tartaric acid doses at different deliming pHs and times

\begin{tabular}{lcc}
\hline \multicolumn{2}{c}{ Factor } & Tartaric acid dose $(\%)$ \\
\hline Time (min) & 45.00 & $0.92 \pm 0.31^{\mathrm{a}}$ \\
& 60.00 & $0.98 \pm 0.32^{\mathrm{b}}$ \\
& 75.00 & $1.06 \pm 0.33^{\mathrm{c}}$ \\
$\mathrm{pH}$ & 4.00 & $1.40 \pm 0.08^{\mathrm{a}}$ \\
& 5.00 & $0.86 \pm 0.05^{\mathrm{b}}$ \\
& 6.00 & $0.70 \pm 0.06^{\mathrm{c}}$ \\
\hline
\end{tabular}

Note: Means in the same column with different superscripts differ significantly $(\mathrm{p}<0.05)$

Table 3. Initial and final $\mathrm{pH}$ solution at different deliming $\mathrm{pHs}$ and times

\begin{tabular}{cccc}
\hline Time $(\mathrm{min})$ & $\mathrm{pH}$ & $\begin{array}{c}\text { Initial } \mathrm{pH} \\
\text { solution }\end{array}$ & $\begin{array}{c}\text { Final } \mathrm{pH} \\
\text { solution }\end{array}$ \\
\hline 45.00 & 4.00 & 2.30 & $4.15 \pm 0.02$ \\
& 5.00 & 2.39 & $5.11 \pm 0.09$ \\
60.00 & 6.00 & 2.41 & $6.06 \pm 0.14$ \\
& 4.00 & 2.28 & $3.96 \pm 0.04$ \\
75.00 & 5.00 & 2.36 & $4.92 \pm 0.16$ \\
& 6.00 & 2.39 & $5.80 \pm 0.27$ \\
& 4.00 & 2.23 & $4.23 \pm 0.06$ \\
& 5.00 & 2.34 & $5.10 \pm 0.27$ \\
& 6.00 & 2.36 & $5.90 \pm 0.17$ \\
\hline
\end{tabular}




\section{The Decrease of Calcium Content in the Pelt}

The result showed that there was a decrease in calcium content in the pelt in response to the effect of final $\mathrm{pH}$ and deliming time (Table 6). The $\mathrm{pH}$ and deliming time have a significant effect on the decrease of calcium content $(p<0.05)$ on each factor. In addition, the interaction between two factors also showed a significant influence on the decrease of calcium content in the pelt tissue $(p<0.05)$. The highest reduction of calcium content in the pelt was found in the treatment of the final $\mathrm{pH}$ of 5. The longer the deliming time, the higher the levels of calcium removed from the pelt tissue (Table 6).

Table 6 showed that the treatment of 75 minutes deliming time with a final $\mathrm{pH}$ of 5 caused the highest reduction of calcium content in pelt tissue, i.e., $53.66 \pm 4.72$ $\%$, while the lowest calcium reduction was produced by the treatment of 45 minutes deliming time with a final $\mathrm{pH}$ of 4 , i.e., $4.63 \pm 0.27 \%$. The treatment of 75 minutes deliming time with a final $\mathrm{pH}$ of 5 was not significantly different compared to the conventional treatments, but it was significantly different compared to 60 minutes deliming time with the final $\mathrm{pH}$ of 5 . The treatment of 60 minutes deliming time with the final $\mathrm{pH}$ of 5 was not significantly different from conventional treatments, i.e., $49.10 \pm 1.40 \%$ and $50.98 \pm 4.11 \%$, respectively (Table 6 ). Therefore, the treatment of 60 minutes deliming time with the final $\mathrm{pH}$ of 5 was determined as the best treatment among the others.

Table 4. Decrease of pelt thickness based on different deliming pHs or times

\begin{tabular}{ccc}
\hline Factor & & $\begin{array}{c}\text { Decrease rate of pelt } \\
\text { thickness }(\%)\end{array}$ \\
\hline Time (min) & 45.00 & $36.92 \pm 0.31^{\mathrm{a}}$ \\
& 60.00 & $39.25 \pm 0.32^{\mathrm{b}}$ \\
$\mathrm{pH}$ & 75.00 & $40.60 \pm 0.33^{\mathrm{b}}$ \\
& 4.00 & $36.26 \pm 0.08^{\mathrm{a}}$ \\
& 5.00 & $42.74 \pm 0.06^{\mathrm{b}}$ \\
& 6.00 & $37.78 \pm 0.05^{\mathrm{a}}$
\end{tabular}

Note: Means in the same column with different superscripts differ significantly $(\mathrm{p}<0.05)$.

Table 5. Decrease of pelt thickness at different deliming pHs and times compared to conventional process

\begin{tabular}{ccc}
\hline Time (min) & $\mathrm{pH}$ & $\begin{array}{c}\text { Decrease of pelt } \\
\text { thickness }(\%)\end{array}$ \\
\hline 45.00 & 4.00 & $35.81 \pm 0.87^{\mathrm{a}}$ \\
& 5.00 & $39.08 \pm 0.86^{\mathrm{ab}}$ \\
60.00 & 6.00 & $35.87 \pm 3.20^{\mathrm{a}}$ \\
& 4.00 & $36.37 \pm 3.10^{\mathrm{ab}}$ \\
75.00 & 5.00 & $43.55 \pm 2.32^{\mathrm{c}}$ \\
& 6.00 & $37.83 \pm 1.16^{\mathrm{ab}}$ \\
& 4.00 & $36.61 \pm 1.35^{\mathrm{ab}}$ \\
& 5.00 & $45.58 \pm 1.98^{\mathrm{c}}$ \\
Conventional & 6.00 & $39.62 \pm 0.54^{\mathrm{b}}$ \\
\hline
\end{tabular}

Note: Means in the same column with different superscripts differ significantly $(\mathrm{p}<0.05)$.

\section{The Physical and Chemical Properties of the Wet Blue}

Based on the analysis of some previous variables, the deliming time of 60 minutes and a final $\mathrm{pH}$ of 5 was the best treatment. The wet blue produced from this treatment was further analyzed regarding its physical and chemical qualities. In terms of physical quality, the produced wet blue had met the specified standards (Table 7). The physical quality of the produced wet blue had the higher values compared to the minimum standard, i.e., the tensile strength for about $25.50 \pm 0.77$ $\mathrm{N} \mathrm{mm}^{-2}$, the tear strength for about $49.70 \pm 1.39 \mathrm{~N} / \mathrm{mm}$, shrinkage temperature for about $105 \pm 1.76^{\circ} \mathrm{C}$, and chromium oxide contents for about $3.62 \pm 0.05 \%$. However, the elongation value was still below the standard, i.e., $56.17 \pm 5.05 \%$ (Table 7 ).

\section{The Characteristics of Wastewater}

The result showed that the produced wastewater had a high quality, indicated by the ammonia content. Ammonia content in wastewater was $61.15 \pm 0.61 \mathrm{mg} / \mathrm{L}$. Meanwhile, the values of the other variables were too high, such as the COD for about $1207 \pm 10.50 \mathrm{mg} / \mathrm{L}$, the BOD for about $374 \pm 7.48 \mathrm{mg} / \mathrm{L}$, the TSS for about 300 $\pm 7.50 \mathrm{mg} / \mathrm{L}$, and the TDS for about $4665 \pm 56.91 \mathrm{mg} / \mathrm{L}$ (Table 8).

\section{DISCUSSION}

\section{The Decrease of Pelt Thickness}

The liming stage is a part of the tanning process that caused skin swelling due to the presence of lyotropic effects, osmotic swelling, and charge effects (Covington \& Wise, 2019). This effect was stimulated by the increase of $\mathrm{pH}$ in the solution (Beghetto et al., 2013). The increase in $\mathrm{pH}$ affected the change of isoelectric points on the skin.

Meanwhile, deliming stage in the tanning process was done for deswelling or depleting the pelt. That process was indicated by a decrease in pelt thickness. The decrease of pelt thickness after the deliming was

Table 6. Decrease of calcium content at different deliming pHs and times compared to conventional process

\begin{tabular}{ccc}
\hline Time $(\mathrm{min})$ & $\mathrm{pH}$ & Calcium content $(\%)^{\mathrm{dc}}$ \\
\hline 45.00 & 4.00 & $4.63 \pm 0.27^{\mathrm{a}}$ \\
& 5.00 & $14.36 \pm 1.28^{\mathrm{b}}$ \\
60.00 & 6.00 & $13.60 \pm 0.97^{\mathrm{b}}$ \\
& 4.00 & $13.10 \pm 1.05^{\mathrm{b}}$ \\
75.00 & 5.00 & $49.10 \pm 1.40^{\mathrm{f}}$ \\
& 6.00 & $39.42 \pm 1.71^{\mathrm{d}}$ \\
& 4.00 & $21.44 \pm 1.20^{\mathrm{c}}$ \\
Conventional & 5.00 & $53.66 \pm 4.72^{\mathrm{g}}$ \\
\hline
\end{tabular}

Note: $d c=$ dry content; Means in the same column with different superscripts differ significantly $(\mathrm{p}<0.05)$. 
Table 7. Wet blue characteristics at the best treatment on $\mathrm{pH} 5$ and 60 minutes

\begin{tabular}{|c|c|c|c|c|c|}
\hline & \multicolumn{5}{|c|}{ Characteristics measured } \\
\hline & $\begin{array}{l}\text { Tensile strength } \\
\qquad\left(\mathrm{N} / \mathrm{mm}^{2}\right)\end{array}$ & Elongation (\%) & $\begin{array}{c}\text { Tear strength } \\
(\mathrm{N} / \mathrm{mm})\end{array}$ & $\begin{array}{c}\text { Shrinkage } \\
\text { temperature }\left({ }^{\circ} \mathrm{C}\right)\end{array}$ & $\begin{array}{c}\text { Chrome oxide } \\
\text { content (\%) }\end{array}$ \\
\hline Sample & $25.50 \pm 0.77$ & $56.17 \pm 5.05$ & $49.70 \pm 1.39$ & $105 \pm 1.76$ & $3.62 \pm 0.05$ \\
\hline $\mathrm{SNI}^{*}$ & 12 & 60 & 12.5 & - & 2.5 \\
\hline Unido & 10 & 60 & 15 & - & - \\
\hline
\end{tabular}

Source: BSN (1998).

Table 8. Wastewater characteristic of deliming process at the best treatment on $\mathrm{pH} 5$ and $60 \mathrm{minutes}(\mathrm{mg} / \mathrm{L}$ )

\begin{tabular}{lccccc}
\hline & \multicolumn{4}{c}{ Characteristics measured } \\
\cline { 2 - 5 } & Ammonia & COD & BOD & TSS & $300 \pm 7.50$ \\
Treatment & $61.15 \pm 0.61$ & $1207 \pm 10.50$ & $374 \pm 7.48$ & $4665 \pm 56.91$ & $3810 \pm 118.49$ \\
Conventional $^{*}$ & $4701.48 \pm 117.54$ & $1605 \pm 16.20$ & $647 \pm 118.49$ & $39505 \pm 359.97$ \\
\hline
\end{tabular}

Note: Source= Nugraha et al. $(2018), C O D=$ chemical oxygen demand (COD), BOD= biological oxygen demand, TSS= total suspended solid, TDS= total dissolve solid.

caused by the process of water transfer from inside to the outside of the pelt (Covington \& Wise, 2019). The higher the number of water comes out, the lower the pelt thickness. The decrease of pelt thickness could be done by lowering the $\mathrm{pH}$ condition below a certain point that could not cause the skin swelling. The treatment of 75 minutes deliming time with a final $\mathrm{pH}$ of 5 was showed the highest reduction in skin thickness, but it was not significantly different from conventional treatments (Table 5). However, the treatment of 60 minutes deliming time with a $\mathrm{pH}$ of 5 gave the best result. This result was caused by the nonsignificant reduction in pelt thickness compared to conventional treatments. In addition, this treatment also did not increase the deliming time and the tartaric acid was lower than the previous treatment.

\section{The Decrease in Calcium Content of the Pelt}

The presence of lime in the pelt tissue was the effect of the previous stage, namely the liming process. The lime on the pelt could cause the formation of calcium carbonate crystals resulted in the uneven leather color at the dyeing stage. Therefore, deliming process is aimed to remove the lime found in the pelt. The removal of lime from the pelt could be indicated by the decrease of calcium ions in the pelt.

Table 6 showed that tartaric acid had a good ability to substitute ammonium sulfate as a deliming agent. In addition, the deliming time also affected the percentage of removed calcium ions from the pelt tissue. The longer the deliming time, the longer the contact time between the deliming agent and the pelt tissue with a final result in the higher calcium removed. The mode of action of tartaric acid was the reaction between tartrate ions and calcium ions to form calcium tartrate. The tartaric acid was a chelating agent with its capability to bind to minerals (Wuana et al., 2010; Rabizadeh et al., 2014). The reaction was stated below,

$2 \mathrm{C}_{3} \mathrm{H}_{5} \mathrm{O}_{4} \mathrm{COOH}+\mathrm{Ca}(\mathrm{OH})_{2} \rightarrow \mathrm{Ca}\left(\mathrm{C}_{3} \mathrm{H}_{5} \mathrm{O}_{4} \mathrm{COO}\right)_{2}+2 \mathrm{H}_{2} \mathrm{O}$ or

$2 \mathrm{C}_{3} \mathrm{H}_{5} \mathrm{O}_{4} \mathrm{COOH}+\mathrm{Ca}^{2+} \rightarrow \mathrm{Ca}\left(\mathrm{C}_{3} \mathrm{H}_{5} \mathrm{O}_{4} \mathrm{COO}\right)_{2}+2 \mathrm{H}^{+}$
The bond between tartaric acid and calcium ions caused a decrease in calcium content of pelt tissue and then it could reduce the pelt thickness. Other studies reported the similar results by using the other materials, such as paracetic acid, glycolic acid, citric acid, and boric acid (Sirvaityte et al., 2007; Colak \& Kilic 2007; Zeng et al., 2011; Wang et al., 2013; Uddin et al., 2018), that could reduce calcium content of the pelt. Thus, tartaric acid materials could substitute ammonium sulfate because of their abilities to bind to calcium ions.

\section{Physical and Chemical Properties of the Wet Blue}

The deliming process in acid condition by using tartaric acid did not affect the physical and chemical qualities of the wet blue compared to the predetermined standards (Table 7). This result was based on several observed variables, such as tensile strength, elongation, tear strength, shrinkage temperature, and chromium oxide contents. The higher the number of collagens eroded, the higher the number of the tanning agent (chromium sulfate or others) was bound so that the tensile strength could be higher (Dellman \& Brown, 1992). The less open pelt fibers could affect the ease of tanning agent penetrating the pelt. This condition would cause the wet blue or leather to become hard, stiff, brittle, and easily broken (Sharphouse, 1991). The tensile strength was influenced by the fiber components in the pelt (Kanagy, 1977). In addition, the tensile strength and the tear strength were also influenced by the thickness, the direction of collagen fibers, and the angle of collagen fibers to the grain filling (Suparno \& Wahyudi, 2012). Therefore, the structure of the fiber network greatly influences the physical and mechanical properties of wet blue or leather (Liu et al., 2013; Cheng et al., 2014). Meanwhile, the wet blue or leather elongation was affected by the elastin component in the skin, i.e., the higher the elastin component, the higher the elongation. Elastin contributes greatly to the physical properties of the skin and leather because elastin controls the elasticity of the skin and leather (Covington \& Wise, 2019). 
In general, the test of shrinkage temperature in the tanning industry was carried out in boiling water with a temperature of $100^{\circ} \mathrm{C}$. The shrinkage temperature of the present study exceeded the boiling water temperature (Table 7). The high shrinkage temperature was influenced by the type of bonding and the concentration of tanning material in the pelt tissue. The high shrinkage temperature on chrome tanning was caused by the covalent bonds between $\mathrm{Cr}^{3+}$ with active carboxylic groups $\left(\mathrm{COO}^{-}\right)$in collagen (Covington \& Wise, 2019). Covalent bonding was firm and heat resistant up to temperatures above $100^{\circ} \mathrm{C}$ (Mann \& McMillan, 2017). Therefore, the level of chromium oxide in the pelt tissue could affect the shrinkage temperature (O'flaherty et al., 1978). The shrinkage temperature and chromium oxide levels have a linear relationship (O'flaherty et al., 1978). The treatment of 60 minutes deliming time with a final $\mathrm{pH}$ of 5 did not affect the shrinkage temperature, and it still met the standard of leather or wet blue using chrome sulfate.

\section{The Characteristics of Wastewater}

Ammonia was the waste generated by the deliming stage. The generation of ammonia was caused by the usage of ammonium sulfate in this stage (Wang et al., 2012; Hashem et al., 2014). In some cases, ammonia harmed the environment. The use of ammonia increased the BOD and COD in wastewater (Uddin et al., 2018; Chowdhury et al., 2018) and eventually caused the death of aquatic organisms if it was discharged into water bodies due to the nitrification (Hashem et al., 2014; Le et al., 2019). The presence of ammonia in wastewater was very difficult to reduce so that it could increase the production cost for waste handling (Uddin et al., 2018). The ammonia formed during the deliming process with tartaric acid was only $61.15 \pm 0.61 \mathrm{mg} / \mathrm{L}$ and it was lower than conventional treatments with ammonium sulfate additive for about $4702.48 \pm 117.54 \mathrm{mg} / \mathrm{L}$. It indicated that despite using a non-ammonia deliming agent such as tartaric acid, ammonia was still formed. Two possibilities for causing the formation of ammonia is the leftover from the liming stage and the byproducts from the deliming process because the protein was hydrolyzed under acidic conditions. Covington \& Wise (2009) reported that one of the products formed during the liming stage was the ammonia. Ammonia was produced due to the changes in the isoelectric point.

The use of tartaric acid as a deliming agent not only reduced the use of ammonia but also resulted in a good effect on the other variables, such as COD, BOD, TSS, and TDS. The decrease in ammonia content in wastewater was associated with a decrease in the other variables, such as $24.8 \%$ in COD, $42 \%$ in BOD, $92.1 \%$ in TSS, and $88.2 \%$ in TDS. It was indicated that the quality of wastewater produced by the tartaric acid was better than those produced by ammonium sulfate. The tartaric acid usage also had the same results as the others free ammonia deliming studies, namely reducing the pollutants in the formed wastewater as Satisth et al. (2013) that used dry ice, Sui et al. (2012) used various types of acid, and $\mathrm{Hu} \&$ Deng (2015) used supercritical carbon oxide in deliming stage.

\section{CONCLUSION}

Tartaric acid addition in the deliming process and duration of deliming influenced the process of removing lime from the pelt. $\mathrm{pH} 5$ at the end of deliming and 60 minutes were the best treatment in this study. Pelt characteristics showed a decrease in thickness and calcium levels in the pelt, while the wet blue produced still meets existing standards. From the output side of wastewater, its quality was better than the conventional deliming process. Thus, the tartaric acid could be used as a deliming agent to substitute ammonium sulfate.

\section{CONFLICT OF INTEREST}

The researchers state that no conflict of interest with any personal, financial, or other relationships with other people or organizations related to the material discussed in the manuscript.

\section{ACKNOWLEDGEMENT}

We highly appreciate Kemenristekdikti - Kementerian Riset, Teknologi dan Pendidikan Tinggi Indonesia (Indonesia's Ministry of Research, Technology, and High Education) for its research funding and support in accelerated master's program leading to doctorate research grant (PMDSU) with contract number: 1530/ IT3.11/PN/2018.

\section{REFERENCES}

Aleixandre, M. V. G., J. A. M. Roca, \& A. B. Pia. 2011. Reducing sulfates concentration in the tannery effluent by applying pollution prevention technique and nanofiltration. J. Clean. Prod. 19: 91-98. https://doi.org/10.1016/j. jclepro.2010.09.006

APHA. 2017. Standard methods for the examination of water and wastewater. 23th ed. APHA, AWWA, WPCF, Washington.

ASTM. 2001. Annual Book of ASTM Standards. Vol 15.04. West Conshohocken, USA. ASTM.

Beghetto, V., A. Zancanaro, A. Scrivanti, U. Matteoli, \& G. Pozza. 2013. The leather industry: A chemistry insight part I: an overview of the industrial process. Sci. At $\mathrm{Ca}^{\prime}$ Foscari. 2013:13-22

BSN. 1998. SNI 4593: 1998 Kulit Jaket Domba/Kambing. BSN, Jakarta.

Cheng, H. M., M. Chen, \& Z. Q. Li. 2014. The role of neutral salt for the hydrolysis and hierarchical structure of hide fiber in pickling. J. Am. Leather Chem. Assoc. 109: 125-130.

Chowdhury, M. J., Md. T. Uddin., Md. A. Razzaq, Al-Mizan, \& A. H. Quadery. 2018. Ammonia - Reduced deliming using glycolic acid and EDTA and its effect on tannery effluent and quality of leather. J. Am. Leather Chem. Assoc. 113: 212 - 216.

Colak, S. M. \& E. Kilic. 2007. The application of different deliming agents for decreasing ammonium pollution load caused by deliming operation in leather industry and the effects of these deliming agents on leather quality and effluent pollution load. J. Sci. Technol. 1: 252-263.

Covington, A. D. \& W. R. Wise. 2019. Tanning Chemistry: the science of leather: edition 2. RSC Publising, UK.

Dai, G., J. Shang, \& B. Qiu. 2012. Ammonia may play an important role in the cyanobacterial blooms and 
the distribution algal species in shallow freshwater lakes. Glob. Chang. Biol. 18: 1571-1581. https://doi. org/10.1111/j.1365-2486.2012.02638.x

Dellman, H. D. \& E. N. Brown. 1992. Histologi Veteriner. Translated by R. Hartono. Universitas Indonesia Press, Jakarta.

Guthrie, S., S. Giles, F. Dunkerley, H. Tabaqchali, A. Harshfield, B. Ioppolo, \& C. Manville. 2018. The Impact of Ammonia Emissions from Agriculture on Biodiversity. The Royal Society. The RAND Corporation, Santa Monica, Calif., and Cambridge, UK United Kingdom. https://doi. org/10.7249/RR2695

Gallego-Molina, A., J. A. Mendoza-Roca, D. Aguado, \& M. V. Galiana-Aleixandre. 2013. Reducing pollution from the deliming-bating operation in a tannery. Wastewater reuse by microfiltration membranes. Chem. Eng. Res. Des. 91: 369-376. https://doi.org/10.1016/j.cherd.2012.08.003

Ghimire, U., M. Jang, S. P. Jung, D. Park, S. J. Park, H. Yu, \& S. E. Oh. 2019. Electrochemical removal of ammonium nitrogen and COD of domestic wastewater using platinum coated titanium as an anode electrode. Energ. 12: 883. https://doi.org/10.3390/en12050883

Hashem, M. A., A. Islam, S. Paul, \& S. Nasrin. 2014. Generation of ammonia in deliming operation from tannery and its environmental effect: Bangladesh perspective. Int. J. Renew. Energ. Environ. Eng. 2: 266-270.

Hu, J., \& W. Deng. 2015. Application of Supercritical Carbon Dioxide for Leather Processing, J. Clean. Prod. 113: 931946. https://doi.org/10.1016/j.jclepro.2015.10.104

Kanagy, R. J. 1977. Physical and Performance Properties of Leather. Robert E. Krieger Publishing So. Hunting, New York

Keerthi, V. S., M. Mahalakshmi, \& N. Balasubramanian. 2013. Development of hybrid membrane bioreactor for tannery effluent treatment. Desalin. 309: 231-236. https://doi. org/10.1016/j.desal.2012.10.014

Le, T. T. H., J. Fettig, \& G. Meon. 2019. Kinetics and simulation of nitrification at various $\mathrm{pH}$ values of a polluted river in the tropics. Ecohydrol. Hydrobiol. 19: 54-65. https://doi. org/10.1016/j.ecohyd.2018.06.006

Lei, C., Y. Lin, Y. Zeng, Y. Wang, Y. Yuan, \& B. Shi. 2019. A cleaner deliming technology with glycine for ammonia nitrogen reduction in leather manufacture. J. Clean. Prod. 245. https://doi.org/10.1016/j.jclepro.2019.118900

Liu, C. K., N. P. Latona, M. M. Taylor, \& R. J. Latona. 2013. Effects of bating, pickling and crosslinking treatments on the characteristics of fibrous networks from un-tanned hides. J. Am. Leather Chem. Assoc. 108: 79-85.

Mandal, T., D. Dasgupta, S. Mandal, \& S. Datta. 2010. Treatment of leather industry wastewater by aerobic biological and fenton oxidation process. J. Hazard. Mater. 180: 204-211. https://doi.org/10.1016/j.jhazmat.2010.04.014

Mann, B. R., \& M. M. McMillan. 2017. The Chemistry of Leather Industry. https://nzic.org.nz/app/uploads/2017/10/5C.pdf [24 September 2019].

Murti, R. S., C. M. H. Purwanti, \& Suyatini. 2013. Adsorption of ammonia from tannery wastewater using bagasse fly ash. Maj. Kulit, Karet dan Plastik. 29: 85-90. In Indonesian. https://doi.org/10.20543/mkkp.v29i2.195

Nugraha, A. W., O. Suparno, \& N. S. Indrasti. 2018. Material, energy and toxicity analyses (MET) in leather industry for identification of cleaner production strategies. J. Teknol. Ind. Pertan. 28: 48-60. In Indonesian. https://doi. org/10.24961/j.tek.ind.pert.2018.28.1.48

O'Flaherty, F., W. T. Roody, \& R.M. Lollar. 1978. The chemistry and technology of leather. Reinhold Publishing Corporation, New York.

Qiang, X., X. Tang, \& H. Zhang. 2012. Study on clean leather deliming process with sulfonated phthalic magnesium salt.
Adv. Mater. Res. 393-395: 308-311. https://doi.org/10.4028/ www.scientific.net/AMR.393-395.308

Rabizadeh, T., C. L. Peacock, \& L. G. Benning. 2014. Carboxylic acids: effective inhibitors for calcium sulfate precipitation?. Mineral. Mag. 78: 1465-1472. https://doi.org/10.1180/ minmag.2014.078.6.13

Sathish, M., B. Madhan, P. Saravan, J. R. Rao, \& B. U. Nair. 2013. Dry ice - an eco - friendly alternative for ammonium reduction in leather manufacturing. J. Clean. Prod. 54: 289 - 295. https://doi.org/10.1016/j.jclepro.2013.04.046

Sharphouse, J. H. 1991. Leather Technicians's Handbook. Leather Product Association 9th. Thomas Street, London.

Sivakumar, V., C. Ponnusawmy, K. Sudalaimani, T. Rangasamy, C. Muralidharan, \& A. B. Mandal. 2015. Ammonia free deliming process in leather industry based on eco-benign products. J. Sci. Ind. Res. 74: 518- 521.

Sirvaityte, J., V. Valeika, K. Beleska, \& V. Valekiene. 2007. Action of paracetic acid on calcium in limed pelt. J. Soc. Leather Technol. Chem. 91:123.

SLTC. 1996. Official Methods of Analysis. SLTC, Northampton (UK).

Stoller, M., D. Sannino, \& A. Chianese. 2013. Successful filtration of membrane technologies in a conventional purification process of tannery wastewater streams. Membr. 3: 126-135. https://doi.org/10.3390/membranes3030126

Sui, Z., L. Zhang, \& J. Song. 2012. Properties of environment friendly nitrogen - free materials for leather deliming. Adv. Mater. Res. 532-533: 126-130. https://doi.org/10.4028/ www.scientific.net/AMR.532-533.126

Suparno, O. \& E. Wahyudi. 2012. The effects of sodium percarbonate concentration and amount of water in the chamois tanning on the chamois leather quality. J. Teknol. Ind. Pertan. 22: 1-9. In Indonesian.

Uddin, T., M. J. Chowdhury, A. Razzaq, Al Mizan, \& A. H. Quadery. 2018. Ammonia-free deliming using glycolic acid and EDTA and its effect on tannery effluent and quality of leather. J. Ind. Pollut. Control. 34: 1957-1960.

USDA. 2011. Tartaric Acid Handling. Technical Evaluation Report. 1-12. https://www.ams.usda. gov>default $>$ files $>$ media [14 October 2019]

Wang, J. \& Y. Liu. 2011. Study on the treatment of tannery wastewater with the high concentration of ammonia nitrogen by MBR. Appl. Mech. Mater. 71-78: 2186-2189. https:// doi.org/10.4028/www.scientific.net/AMM.71-78.2186

Wang, Y., Y. Zeng, X. Chai, X. Liao, Q. He, \& B. Shi. 2012. Ammonia nitrogen in tannery wastewater: distribution, origin, and prevention. J. Am. Leather Chem. Assoc. 107: 40-50.

Wang, Y., Y. Zeng, X. Liao, W. Zhang, \& B. Shi. 2013. Removal of calcium from pelt during bating process: an effective approach for non-ammonia bating. J. Am. Leather Chem. Assoc. 108: 120-127.

Wuana, R. A., F. E. Okieimen, \& J. A. Imborvungu. 2010. Removal of heavy metals from a contaminated soil using organic chelating acids. Int. J. Environ. Sci. Technol. 7: 485496. https://doi.org/10.1007/BF03326158

Yunnen, C., X. Changshi, \& N. Jinxia. 2016. Removal of ammonia nitrogen from wastewater using modified activated sludge. Pol. J. Environ. Stud. 25: 415-425. https://doi. org/10.15244/pjoes/60859

Zeng, Y., J. Lu, X. Liao, Q. He, \& B. Shi. 2011. Non-ammonia deliming using sodium hexametaphospate and boric acid. J. Am. Leather Chem. Assoc. 106: 257-263.

Zeng, Y., Y. Wang, Y. Song, J. Zhou, \& B. Shi. 2018. A cleaner deliming process using sodium gluconate for reduction in nitrogen pollution in leather manufacture. J. Am. Leather Chem. Assoc. 113: 19-25. 